\title{
マウス唾液と創傷治療に関する基礎的研究
}

河原 康・河合俊彦・酒 向 誠

神野洋輔・河合幹

\section{An experimental study of wound healing and saliva in mice}

\author{
Kou Kawahara - Toshihiko Kawai • Makoto Sakou \\ Yousuke Jinno • Tsuyoshi KawaI
}

\begin{abstract}
Generally, a mouth wound heals faster than one in any other region of the body. Biological factors in saliva, such as kallikrein, amilase, lysozyme, immuno-globulin, renin, nerve growth factor and epidermal growth factor may influence wound healing-that is epithelialization, contraction, collagen synthesis, and scar remodelling. In this paper, we report the effect of saliva to the standard sacral open wounds of mice, varied with the caging method as follows:

group 1: wounded mouse caged in isolation.

group 2: two wounded mice caged together.

group 3: wounded mouse caged with mouse priorly sialectomized (Sublingual and submandibular gland). The wound area was measured every 7 days after surgery.

We obtained the results as follows:

1. We realized significant differences in each group. These findings suggest that biological factors in saliva accelerate wound healing.

2. Difference in the wound healing process between groups 2 and 3 suggests that the amount and characterization of saliva effect on the wound contraction.
\end{abstract}

Key words: wound healing (創傷治療), mice (マウス), saliva（唾液）

I. 緒

言

一般に口腔内の創傷は, 身体他部に比べ治癒が早く, 唾液による影響が深く関係していると考えられている。 唾液腺中には, Epidermal Growth Factor (EGF), Nerve Growth Factor (NGF), 免疫グロブリン, ライ ソザイム, カリクレイン, レニンなどの生物学的活性物 質が含まれている( 5) が, それらの生理活性物質の唾液 内の存在意義についてはほとんどあきらかにされていな い. しかしこれらの生物学的活性物質は, 実験的には上 皮化, 創収縮, コラーゲン合成, 瘢痕形成などに代表さ れる 創傷治癒過程と関連することが 報告され，とくに

愛知学院大学歯学部第 2 口腔外科学教室 (主任：河合 幹教授)

The Second Department of Oral and Maxillofacial Surgery, School of Dentistry, Aichi Gakuin University (Chief: Prof. Tsuyoshi Kawai)

受付日: 平成 4 年 1 月 16 日
EGF，NGF については実験病理学, 細胞培養などの手 法によって, 幅広く研究されている. EGF は in vivoに 扣いて表皮細胞層の増殖と角化促進作用があり ${ }^{6)}$, in vitro において培養系表皮細胞の増殖, 線維芽細胞のグリコサ ミノグリカン合成促進作用があるといわれている7). また創収縮に大さく関与する線維芽細胞によって, NGF が分泌されることが知られている8).

以上のように基礎的な研究から，少なくとも創傷治瘉 と唾液中のそれぞれの生理活性物質との間に何らかの関 連があると推論されているが9)，これらの個々の物質の 作用のみでは, 生態系に拈ける唾液全体の創傷治癒に対 する影響を把握することは難しいと考えられる，そこで 今回われわれは，ICR 系雌マウスを使用し，その背部 皮膚に全層皮膚欠損創を作成し，その後それぞれ飼育条 件を変えることによって，唾液の有無による創傷治癒の 変化を生じさせ, 定量的に観察したので若干の考察を加 えて報告する． 


\section{II. 実 験 材 料}

実験動物は， $7 \sim 8$ 週齢（体重30４0 g ）の ICR 系 雌性マウス（静岡県実験動物農業共同組合）を使用, 実 験中室温 $23 \pm 1{ }^{\circ} \mathrm{C}$, 湿度 $60 \pm 10 \%$ の環境下で飼育し, 固 形飼料 (CMF一オリエンタル酵母工業)を与兄, 水道水 を給水瓶にて自由摂取させた。

\section{III. 実 験 方 法}

\section{1. 皮膚全層欠損作製法}

エーテル麻酔下に, 背部中央の仙骨部付近を剃毛し, 24 時間後にネンブタール腹腔内麻酔下に替刃メス（フェ ザー社 No. 15) を使用し, 同部広背筋膜上に直径 $10 \mathrm{~mm}$ の円形皮膚全層欠損を作成した。

\section{2. 実験条件}

背部に作創したマウスは, 以下の 3 通りの条件下で飼 育し創傷治癒過程を比較した。

1) 単独群：1ケージ中に単独で飼育した群（創の自 然治癒をみるための対照群）

$$
\text { ケージ数 }=5
$$

2) ペアー群：1ケージ中に 2 匹ペアーで飼育した群 （マウス相互で創を䑛めあい，創は唾液の作用を受ける 群)

$$
\text { ケージ数 }=4
$$

3）唾液腺摘出ペアー群 : 顎下腺と舌下腺を摘出した マウスと作創したマウスをペアーで飼育した群

$$
\text { ケージ数 }=4
$$

エーテル麻酔下, 頸部正中を $5 \%$ クロールヘキシジン 溶液で消毒. 同部に約 $1 \mathrm{~cm}$ の皮膚切開をおいた後両側 の顎下腺, 舌下腺を摘出したものを唾液腺摘出群とし た，切開創は，絹采にて縫合して一次閉鎖した，摘出手 術は実験の 1 週間前に行い, 動物に体重变化がなくまた 他の病的状態がないことを確認して実験に使用した.

\section{3. 創収縮の定量的観察法}

創傷治癒過程を肉眼的, 定量的にとらえるために, 創 形成日を 0 日とし，24時間ごとに 7 日間写真撮影を行い 面積計測を行った。

撮影時, メジャーをいれた透明なプラスチックプレー トをマウス背部創面におき創面がフラットに表示される ようにし, $35 \mathrm{~cm}$ の固定焦点距離で写真撮影を行った. ついでメジャーを利用して写真を同一に拡大後, イメー ジスキャナー (EPSON 社, GT 4000) でパーソナルュ ンピュータ (Macintosh SE) に入力した後, 面積計測 機能をもつアプリケーション（Canvas 2.0）を使用して 創面の画像をトレースし面積を求めた（図1）. 創形成 直後の面積を 100 とし，その後の創面積を\%で表した。 また各データは各個体の面積測定值の平均土 1 標準偏差

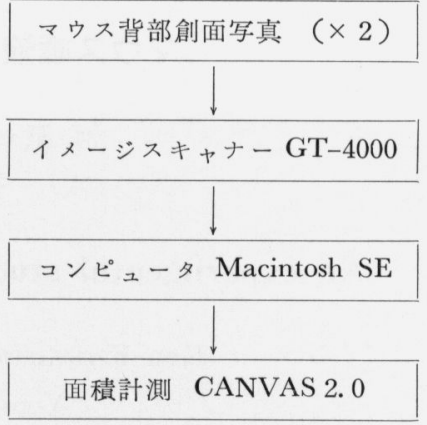

図 1 創面積計測法

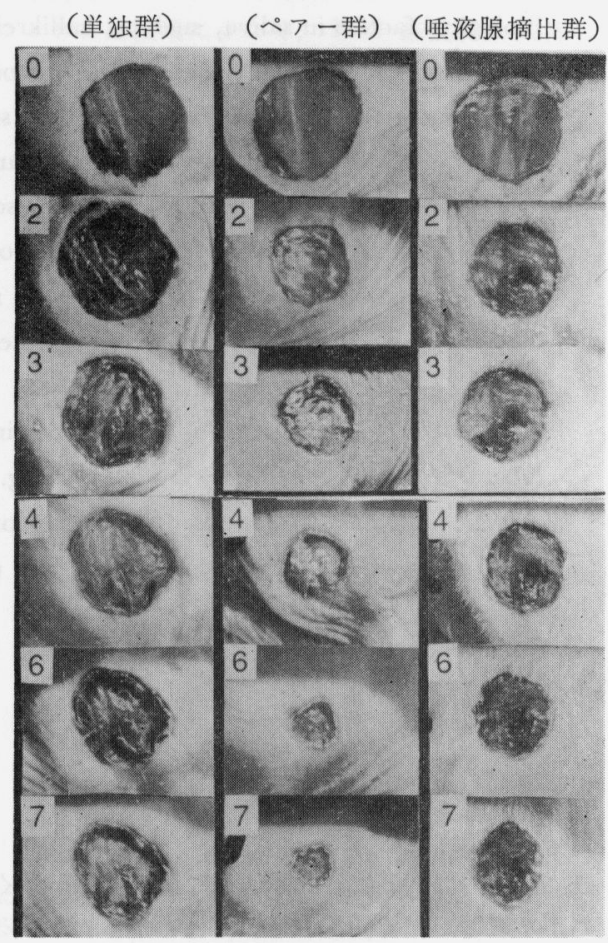

写真 1 各写真の左隅の数字は創形成後の 経過日数を示す.

值 (SD) で表した，各群間の有意差検定には，対応のな いt 検定を使用し，5\%の危険率で有意差を判定した。

IV. 結

果

単独群，ペアー群の間で作創後 3 日目ごろより創収縮 にあきらかな差が認められ，ペアー群の方により早い創 の収縮を認めた（写真 1, 図 2).

創面積の計測值の経日的変化は各群間であきらかな差 がみられた． 創面積減少がもっとも早いのはペアー群 で, 次に唾液腺摘出ペアー群, 単独群の順であった。 


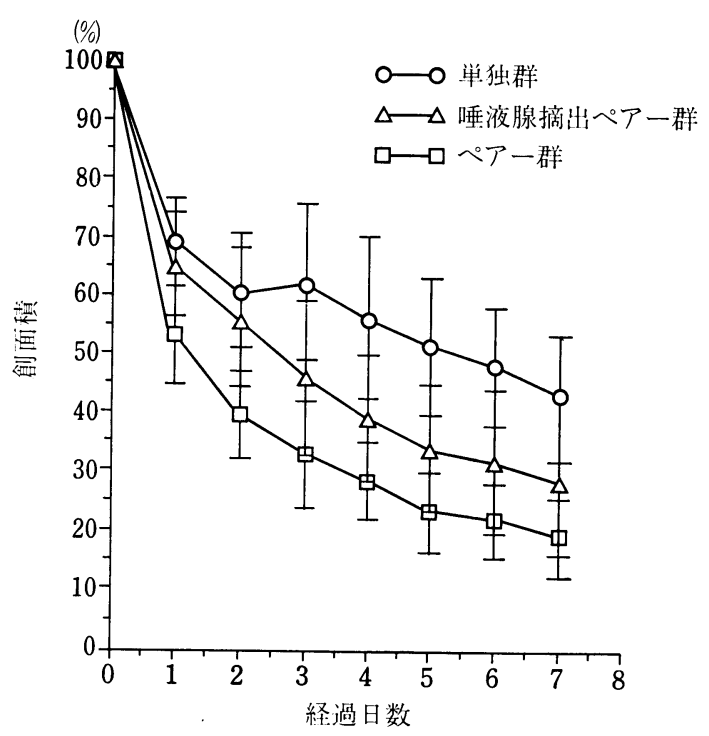

図 2 実験期間中に括ける単独群，ペアー群，唾液 腺摘出ペアー群の創面積減少経過

（創形成直後の面積を100として，その後の面積を\% 表示した)

アー群と単独群の創面積の差は術後 1 日目で約 $15 \%, 2$ 日目で約 $22 \% ， 3$ 日目からその差は著しくなり約 $30 \%$ 程 度の差が認められた. 唾液腺摘出ペアー群も単独群より 創面積の減少が速い傾向があったが，ペアー群に比べれ ば遅延傾向が認められ, 創面積の減少曲線はペアー群と 類似していた（写真1, 図 2).

\section{V. 考察}

Madden ${ }^{10)}$ らは，われわれと同様の実験方法における 測定誤差について報告して扣り，数人の計測者によって 同一の写真をくり返し計測すると $2 \%$ 以下の測定誤差が あると述べている. われわれも予備実験に扣いて写真撮 影, トレースと面積計測をくり返し，同一創面に和いて 計測すると約 $1 \%$ 以内の測定誤差にとどまるとの結果を 得たので以降の実験を継続した。.したがって今回の実験 結果におけるペアー群・唾液腺摘出ペアー群と単独群と の実験結果間にみられる創収縮過程の著しい相違は, 創 形成後の飼育環境すなわち互いの創の派め合いの有無を 反映していると考えられる。マウス唾液中には， EGF， $\mathrm{NGF}$ ，カリクレイン，アミラーゼ，免疫グロブリン， ラ イソザイム，レニンなどの生物学的活性物質が含まれて おり, これらが創縁からの上皮細胞の遊走, 増殖に基づ く上皮再生之, 創縁の皮膚全層の求心性移動による創収 縮の $2 つ^{11)}$ に代表される創面の治癒過程に何らかの影響 を及ぼしていると現在考えられている。
EGF は，創傷治瘉に関する in vitro の実験でマウス の線維芽細胞や表皮細胞系など末分化な分裂期細胞の増 殖, 分化を刺激する一方, 創傷治瘉の初期に細胞遊走の 支持組織であるフィブロネクチンの合成を促進するとも いわれている7). また表皮細胞層の増殖と角化促進を有 することも病理的検索によって知られている6 ${ }^{6}$.

$\mathrm{Li} ら^{12)}$ は創傷治癒に関して，創縁および創床の線維 芽細胞の細胞遊走に NGF が関与していると考察してい る. また逆に線維芽細胞が NGF を分泌し創傷治瘉に関 与しているとの報告も存在する ${ }^{8)}$.

なお，EGFは，雄マウス䪽下腺 $1 \mathrm{~g}$ あたり $1 \mathrm{mg}$ と 多量に含まれており，雌ではその約 $1 / 15$ と性差がある. NGF は，雄マウス顎下腺 $1 \mathrm{mg}$ あたり 404.00土50.300 ng, 雌では $51.00 \pm 3.300 \mathrm{ng}$ の含有量であるとされてい $ろ^{9)}$.

以上のことから今回の実験では EGF，NGF の影響を 極力排除する目的で雌マウスを使用したが，われわれの 実験結果は両者の含有量が少ない雌でも唾液の存在によ る影響を示しており，実験に雄を使用すればより顕著な 相違を得たのではないかと考えられる。

本実験ではペアー群と唾液腺摘出ペアー群の間に大き な差がみられたが, この差は唾液量の差, あるい顎下 腺のないことによる差を示すものと考えられる，また唾 液腺摘出群が単独群より治癒促進傾向を示したことは, 同様に耳下腺・小唾液腺よりの分泌唾液の影響を示唆し ていると考えられる。

しかし Hutson の述べる創の licking の結果すなわち 痂皮の除去による影響9) も否定できないので，本実験 に打ける創面積収縮率の差（図2）は，マウスが創を licking することによる唾液そのものの影響に，舌の機 械的因子が関与していることも考えられる.

創傷治癒に伴ら創収縮機序については, 線維芽細胞あ るいはコラーゲン線維が大きく関与するとの従来の説に 対し, 最近では Gabbiani ${ }^{13)}$ による筋線維芽細胞説も広 く支持されている，筋線維芽細胞 (myofibroblast) は肉 芽組織中に存在し, 形態学的に線維芽細胞と平滑筋細胞 の両者の特徵を部分的に備えた細胞で, 肉芽組織に平滑 笳細胞拮抗剂を局所的に塗布することにより，創収縮が 一時停止することが実験的に知られている ${ }^{10,14)}$.

今回の実験結果のみでは, 唾液は創傷治瘉の 2 つの要 素 : すなわち筋線維芽細胞による創縁の皮膚全層の求心 性移動, あるいは創縁からの上皮細胞の遊走・増殖に基 づく上皮再生のいずれに 影響しているかは明確でない が，比較的早期から治癒に差を認めることから恐らく両 者に影響しているのではないかと推察される，今後この 点については, さらに詳細に検討する必要があると考え ている. 


\section{VI. 結}

論

ICR 系マウスを使用し，その唾液が背部皮膚の創傷 治癒に及ぼす影響を定量的に検討した。

1. ペアー群・唾液腺摘出ペアー群と単独群との間に 創収縮率に有意の差がみられ, 唾液中の生物学的活性因 子が創傷治瘉に促進的に作用することが推測された.

2. 唾液腺摘出ペアー群とペアー群の差は, 唾液の量 と質が創収縮に影響することを推測させた。

\section{引 用 文 献}

1) Cohen, S. and Carpenter, G.: Human epidermal growth factor: chemical and biological properties. Proc Nat Acad Sci USA 72: 1317-1321 1975.

2) Varon, S., Nomura, J., et al.: The isolation of the mouse nerve growth factor proyein in a high molecular weight form. Biochemistry 6: 2202-2209 1967.

3) Fleming, A.: On a remarkable bacteriolytic element found in tissues and secretions. Proc Roy Soci Lond (Biol) 93: 306-317 1922.

4) Werle, E. and Roden, P.: Uber des Vorkommen von Kallikrein in der Speicheldruesen und in Mundspeichel. Biochem Z 286: 2132191936.

5) Gresik, E., Michelakis. A., et al.: Immunocytochemical localization of renin in the submandibular gland of the mouse. J Histochem
Cytochem 26: 855-861 1978.

6) Franklin, J.D., Lynch, J.B.: Effects of topical applications of epidermal growth factor on wound healing. Plast Reconst Surg 64: 7667701979.

7) Falanga, V., Zitelli, J.A., et al.: Wound healing. Periodic synopsis. J Am Acad Dermatol 19: 559-563 1988.

8) Young, M., Oger, J., et al.: Selection of a nerve growth factor by primary chick fibroblast cultures. Science 187: 361-362 1975.

9) Hutson, J.M., Niall, M., et al.: Effect of salivary glands on wound contraction in mice. Nature 279: 793-795 1979.

10) Madden, J.W., Morton, D. J., et al.: Contraction of experimental wounds. I. Inhibiting wound contraction by using a topical smooth muscle antagonist. Surgery 76: 8-15 1974.

11) Luccioli, G.M., Kahn, D.S., et al.: Histologic study of wound contraction in the rabbit. Ann Surg 160: 1030-1040 1964.

12) Li, A.K.C. and Maryjokoroly.: Mechanical and humoral factors in wound healing. $\mathrm{Br} \mathrm{J}$ Surg 68: 738-743 1981.

13) Gabbiani, G., Hirschel, B. J., et al.: Granulation tissue as contractile organ: A study of structure and function. J Exp Med 135: 719-734 1972.

14) Morton, D. Jr., Madden, J.W., et al.: Effect of local smooth muscle antagonist on wound contraction. Surg Form 23: 511-512 1972. 